\title{
712 電磁式補助人工心臓の駆動制御に関する研究
}

A Control for Optimal Driving of the Direct Electromagnetic Ventricular Assist Device

\author{
○福長 一義 （東京電機大） \\ Kazuyoshi FUKUNAGA, Tokyo Denki University, Hatoyamamachi, Hikigun, Saitama
}

\section{大沼 健太郎 （東京電機大）＼cjkstart伊藤＼cjkstart洋平（東京電機大）～住倉 博仁 （東京電機大）}

Kentarou OHNUMA, Tokyo Denki University Youhei ITOH, Tokyo Denki University Hrohito SUMIKURA, Tokyo Denki University

舟久保 昭夫 (東京電機大)

Akio FUNAKUBO, Tokyo Denki University
福井 康裕 (東京電機大)

Yasuhiro FUKUI, Tokyo Denki University

\begin{abstract}
This paper reports on the control system that drives the Direct Electromagnetic Ventricular Assist Device (DEM-VAD) which is currently under development. DEM-VAD driven by Linear Oscillatory Actuator (LOA) has the structure, which makes the pusher-plate attached to the Mover reciprocate directly. The principal feature of our LOA is that the thrust generated by the same input electric power differs according to the positions and the drive directions of the mover. The mover consists of permanent magnets, therefore in order to generate the control signal according to the pusher-plate position and the drive direction, the information on the position detected by the hal I sensor was used. As a result of driving a pump in a mock circulatory system, the maximum pump rate in which full fill full eject drive was possible were $167 \mathrm{bpm}$ in drive voltage $10 \mathrm{~V}$ (Afterload $100 \mathrm{~mm} \mathrm{Hg}$, Preload $10 \mathrm{mmHg}$ ). At this time, input power was $8.5 \mathrm{~W}$, pump output was $7.2 \mathrm{~L} / \mathrm{min}$, and efficiency was $18.9 \%$. We tried to control the obstruction of the pump inlet occurred using change of slope of the hall sensor output voltage waveform. Consequently, the possibility was suggested of removing the obstruction of the pump inlet which occurred.
\end{abstract}

Key Words: Linear Oscillatory Actuator, Ventricular Assist Device, Control

1.はじめに

内科的治療では救命困難な重症心不全患者を治療する目 的で心臓移植が行われている。1999 年より本邦においても脳 死からの心臟移植が再開されたが、ドナ一心蔵の不足は深刻 である。また、心臓移植待機患者の移植待機期間は長期化し ており、補助人工心蔵は、心蔵移植までのブリッジとして重 要な治療機器となっている。

本研究では、運動変換機構を用いずに往復運動が得られる リニア振動アクチュエータ(Linear Oscillatory Actuator: 以下 LOA $)^{1)}$ を使用した電磁式補助人工心臟(Direct Electromagnetic Ventricular Assist Device: 以下 DEM-VAD)の開発を行ってい る。現在まで模擬循環回路による試作ポンプの評価を行って きた 2)。ポンプ評価のための DEM-VAD 駆動には駆動信号に 正弦波のような固定波形を入力してきた。今後、動物実験や 実用化に向けて完全充満・完全駆出(Full Fill / Full Eject: 以下 FF/FE)駆動等の制御が必要であると考えられた。そこで本研 究では、DEM-VADの駆動制御システムの開発を目的とする。

\section{2. 方法}

固定波形による駆動では、自然心葴の拍動下のような負荷 が変動する条件での FF/FE 駆動が困難であると考えられた。 また、脱血時に心室壁を吸い付けるなど流路に障害を生じる 可能性が考えられた。そこで、計測が容易でポンプの駆動状 態と関係が強いと考えられるプッシャープレートの位置情 報をフィードバックすることにより駆動制御を行った。

LOA は、インバータ回路によって駆動信号に対応したス イッチングを行うことで駆動した。プレート位置に応じて生 成した駆動信号は、パーソナルコンピュータおよびアナログ 入出力可能な $\mathrm{I} / \mathrm{O}$ ボード(DAQ card, National Instruments)を用 いて出力した。
2-1 プッシャープレート位置の検出 DEM-VADは、LOA の可動子によってプッシャープレートを直接往復運動させ る特徵を有した。LOA の可動子は、永久磁石で構成されて いるため、ホール素子 (HW105A，旭化成電子) を用いてプレ 一ト(可動子)の位置を検出した(図 1)。

2-2 制御方法 対象としたLOA は、同じ入力電力におい て、可動子の位置、駆動方向によって生じる推力が異なる ${ }^{2)}$ 。 そこで、可動子の往復運動のストロークを駆出方向・充満方 向でそれぞれ 8 段階に分割し、各位置・駆動方向に応じて駆 動信号を生成した。ホールセンサ出力波形に完全充満、完全 駆出時でそれぞれ䦨値を設定して充満・駆出を切換えた(図 2-(1)。また、完全充満·完全駆出直後にそれぞれ待機時間を 設けることで、定拍動数駆動を可能とした(図 2-(2)。

DEM-VADはプッシャープレートが可動子に直接固定され ており、能動的に充満する構造であるため、脱血時に心室壁 を吸い付ける可能性がある。吸い付きが生じた際、脱血が困 難となりプッシャープレートが停滞すると考えられたため、 ホールセンサ出力波形の傾きの変化より吸い付きの判別を 行った。吸い付きが生じた際の回復を期待し、プレート停滞 時に駆動信号を駆出方向へ切り換え、その後一定時間待機し た後再び充満・駆出を切り換える制御とした(図 2-(3)。

\section{3. 実験}

本制御法を用いた駆動状態を検討するため、模擬循環回路 を用いたポンプ駆動実験を行った。実験条件は、LOAの駆 動電源電圧を $10 \mathrm{~V}$ 、前負荷を $10 \mathrm{mmHg}$ 一定とした。後負荷 $100 \mathrm{mmHg}$ 一定で拍動数を変更したとき、拍動数 $120 \mathrm{bpm}$ 一 定で後負荷を変更したときの各条件でポンプを駆動した。 


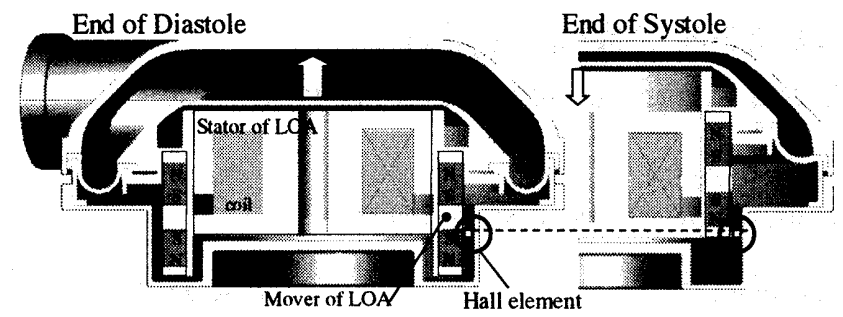

Fig.1 Detection of pusher-plate position

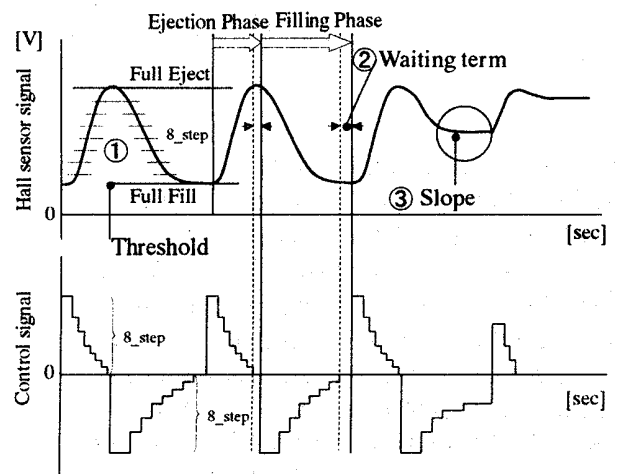

Fig.2 Operation of a control for DEM-VAD

脱血時の吸い付きを想定してポンプ駆動中に Inlet 側の流 路を遮断する実験を行った。このとき流路の遮断部分とポン プ流入口の間の圧力を同時に測定した。

\section{4. 結果}

図 3 に従来より用いている固定波形による駆動状態およ びプッシャープレートの位置・駆動方向に応じて制御を行っ た駆動状態の一例(拍動数 $120 \mathrm{bpm}$, 後負荷 $100 \mathrm{mmHg}$ )を併せ て示した。このとき、固定波形による駆動ではプレート位置 が FF/FE に達した後再び充満・駆出が切り換わるまでの間、 電流が流れ続けているのに対して制御を行った駆動では、

$\mathrm{FF} / \mathrm{FE}$ 後に定拍動数駆動のための待機時間があり、その間電 流が流れていないことが示された。

図4に各条件における固定波形駆動および本制御法による 駆動時の効率特性を示した。本実験の条件において拍動数 $167 \mathrm{bpm}$ まで FF/FE 駆動が可能であった。また、このとき最 大効率 $18.9 \%$ 、最大流量 $7.2 \mathrm{~L} / \mathrm{min}$ を示した(入力電力 $8.5 \mathrm{~W}$ )。

脱血時の吸い付きを想定してポンプ Inlet 側の流路を遮断 したときの駆動状態を図 5 に示した。図 5 より流入口の遮断 に対して、図 2(3に示した制御法に従って動作したことが確 認された。

\section{5. 考察}

図 4 より固定波形駆動に比べて、プッシャープレート位 置・駆動方向に応じて制御したとき、一様に効率の改善が見 られた。また、効率 13 19\%程度で一定であったことから、 拍動数の変更や後負荷の変化においても安定して駆動可能 であると考えられた。

脱血時の吸い付きを想定した動作は、まず流路を遮断する と(図 5(1)、充満が困難となりプッシャープレートが停滞し た。つぎに、ホールセンサ出力波形の傾きから吸い付きと判 別し(図 5(2)、駆動信号を駆出方向に切換えている(図 5(3)。 その後一定時間 (本実験では $1[\mathrm{sec}]$ )待機することで吸い付き が解除されることを期待している。このときポンプ流入部の 圧力が陰圧から陽圧になっていることから(図 5(4))、本制御 法で吸い付きが解除可能であると示唆された。
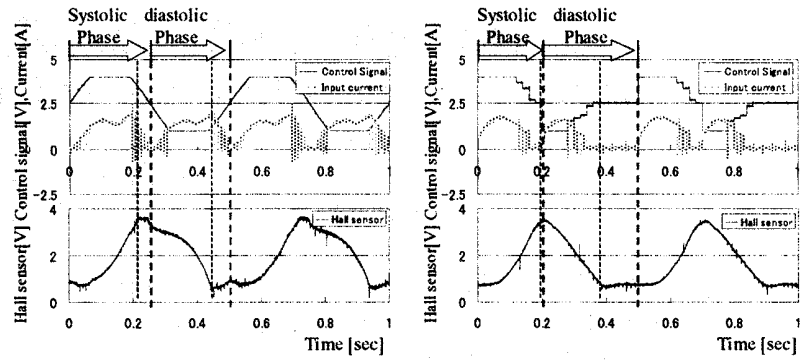

(1) Fixed signal

(2) Controlled signal

Fig. 3 Drive characteristics of DEM-VAD $(100 \mathrm{mmHg}, 120 \mathrm{bpm})$
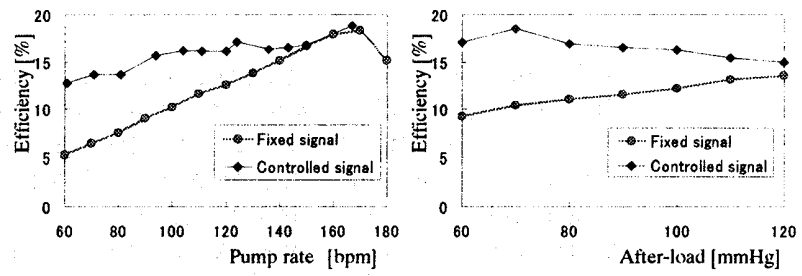

(1) Constant afterload $100 \mathrm{mmHg}$ (2) Constant pump rate $120 \mathrm{bpm}$ Fig.4 Efficiency characteristic

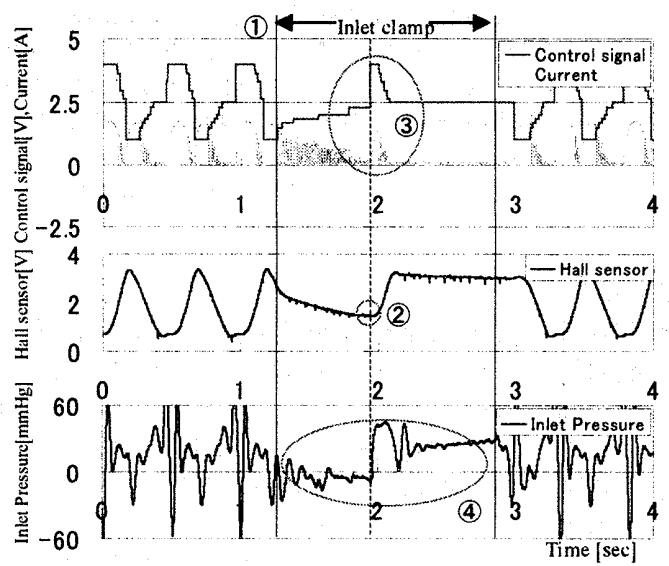

Fig.5 Dealing with the obstruction of the pump inlet occurred

6. まとめ

プッシャープレートの位置情報から、駆動信号を決定する 制御システムを構築し、模擬循環回路を用いて駆動実験を行 い、次の結果が得られた。

（1）前負荷 $10 \mathrm{mmhg}$ 、後負荷 $100 \mathrm{mmHg}$ において FF/FE 駆動 が可能な最大拍動数は $167 \mathrm{bpm}$ であった。このとき入 力電力 $8.5 \mathrm{~W}$ 、拍出量 $7.2 \mathrm{~L} / \mathrm{min}$ 、効率 $18.9 \%$ を示した。

(2) 本制御法による駆動で、固定波駆動と比べて一様に効 率の改善がみられた。最大で 2.7 倍の効率の改善が見ら れた。また、拍動数の変更や後負荷の変化に対して固 定波形と比べて安定した効率で駆動可能であると考え られた。

(3) 模擬循環試験において、本制御によって吸い付きに対 処可能であることが示唆された。

参考文献

1) 福長一義、舟久保昭夫、福井康裕: 補助人工心臓用リニア 振動アクチュエー夕の提案と推力解析，生体医工学，40-4, 201/213(2002)

2) Kazuyoshi FUKUNAGA, Akio FUNAKUBO, Yasuhiro FUKUI: Newly Developed Ventricular Assist Device with Linear Oscillatory Actuator, ASAIO J., 49, 333/339 (2003) 